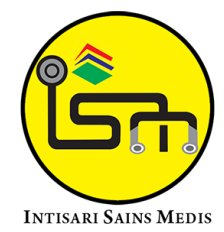

Published by Intisari Sains Medis

\section{Preoperative factors influencing surgical site infections (SSIS) in inguinal hernia patients undergoing tension-free mesh hernia repair at regional public hospitals in Bali}

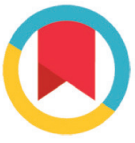

CrossMark

\author{
Putu Anggia Dimitri Pramesti ${ }^{*}$, Made Dharmesti Wijaya ${ }^{2}$, Made Dwi Yoga Bharata ${ }^{3}$
}

${ }^{1}$ Faculty of Medicine and Health Sciences, Universitas Warmadewa, Denpasar, Bali, Indonesia;

${ }^{2}$ Faculty of Medicine and Health Sciences, Universitas Warmadewa, Denpasar, Bali, Indonesia;

${ }^{3}$ Department of Digestive Surgery, Sanjiwani General Hospital Gianyar, Bali, Indonesia;

*Corresponding author:

Putu Anggia Dimitri Pramesti;

Faculty of Medicine and Health Sciences, Universitas Warmadewa, Denpasar, Bali, Indonesia;

anggiadimitri@gmail.com

Received: 2021-05-14

Accepted: 2021-07-20

Published: 2021-08-07

\section{ABSTRACT}

Introduction: Surgical site infection (SSI) is the most common nosocomial infection, affecting one out of three patients undergoing surgical procedures. The incidence of SSI in clean surgical wounds is still higher, especially in inguinal hernia repair. Today, tensionfree mesh hernia repair is the primary method used in inguinal hernia management to reduce the risk of recurrence. This study aims to analyze preoperative factors influencing the incidence of SSIs in inguinal hernia patients that underwent tension-free mesh hernia repair at several regional public hospitals in Bali. Methods: This is a case-control study with samples taken from seven regional hospitals in Bali. Data used in this study were obtained from patients' medical records from 2017-February 2021. Samples included in this study are inguinal hernia patients that underwent tension-free mesh hernia repair and postoperative

check-up. Samples are selected through the purposive sampling method. Statistical analysis was done using SPSS 18.0 software. Univariate and bivariate analysis was performed, and Pearson chi-square and Fisher's exact test were applied.

Results: From the 61 samples in the case group and 61 samples in the control group, the results showed a significant relationship between the incidence of SSIs and elderly patients $(0 \mathrm{R}=2.262,95 \% \mathrm{Cl} 1.086-4.711)$, between SSIs and obesity (OR $=9.057,95 \% \mathrm{Cl} 1.096$ 74.808), and between SSIs and diabetes mellitus ( $O R=$ $9.620,95 \%$ Cl 2.094-44.201).

Conclusion: It is concluded that there is a significant relationship between these preoperative factors and the incidence of SSIs in inguinal hernia patients that underwent tension-free mesh hernia repair at seven regional public hospitals in Bali.

Keywords: Inguinal hernia, surgical site infection, tension-free mesh hernia repair.

Cite This Article: Pramesti, P.A.D., Wijaya, M.D., Bharata, M.D.Y. 2021. Preoperative factors influencing surgical site infections (SSIS) in inguinal hernia patients undergoing tension-free mesh hernia repair at regional public hospitals in Bali. Intisari Sains Medis 12(2): 534-537. D0I: 10.15562/ism.v12i2.1088

\section{INTRODUCTION}

Surgical site infection (SSI) is the most common nosocomial infection, affecting one out of three patients undergoing surgical procedures. ${ }^{1}$ SSI is an infection on the surgical wound or area, happening within 30 days after the procedure ends or up until one year if a prosthesis is placed during the operation. ${ }^{2}$ A surgical wound can be classified as infected if pus is present, accompanied by signs of inflammation such as; redness, pain, swelling, and heat. ${ }^{3}$ The incidence of SSI is influenced by many factors such as; preoperative factors (patient-related), perioperative factors (procedure-related), and postoperative factors (postoperative management). ${ }^{4}$ Age, nutritional status, and diabetes mellitus are some examples of preoperative factors. ${ }^{1,4}$ Perioperative factors include the duration of the procedure and preoperative preparations. ${ }^{5}$ While, wound management is an example of postoperative factors. ${ }^{6}$ Types of surgical wound is also one of the factors influencing the risk of SSI. Clean surgical wounds have the lowest risk $(<2 \%)$ of SSI. ${ }^{7}$ However, several studies show that SSI incidence in clean surgical wounds is still higher than the risk stated. ${ }^{8,9}$ One of the most frequently done clean surgical procedures worldwide is inguinal hernia repair. ${ }^{10}$ Studies show that SSI incidence in inguinal hernia repair is high, despite being categorized as a clean surgical procedure. . $11,12^{12}$

Inguinal hernia is the protrusion of the peritoneum (abdominal wall) with or without internal abdominal organs through the inguinal canal. ${ }^{13}$ There are two types of inguinal hernia, lateral (indirect) inguinal hernia that passes through the inguinal canal, and medial (direct) inguinal hernia that directly protrudes through the Hesselbach triangle. ${ }^{14}$ 
Today, tension-free mesh hernia repair is the main method used in inguinal hernia management to reduce the risk of recurrence. ${ }^{13,15}$ Therefore, this study aims to analyze preoperative factors influencing SSI in inguinal hernia patients undergoing tension-free mesh hernia repair.

\section{METHODS}

This is a case control study on 122 samples with data taken from patients' medical records from RSUD Sanjiwani Gianyar, BRSUD Tabanan, RSUD Klungkung, RSUD Bangli, RSUD Mangusada Badung, RSUD Buleleng, and RSUD Wangaya Denpasar.

Samples are chosen using the purposive sampling method. Data were collected during February-May 2021 on patients who had the procedure between January 2017 and February 2021. Samples are inguinal hernia patients that underwent tension-free mesh hernia repair and did postoperative control within one year after the process was done. Patients with recurrent inguinal hernia, strangulated inguinal hernia, and patients with preoperative anemia are excluded from this study. Patients with incomplete medical records are also excluded from this study.

There are three factors analyzed in this study, namely elderly patients, obesity and diabetes mellitus. Samples are considered elderly patients if they are $\geq 65$ years old when diagnosed with inguinal hernia and had a tension-free mesh hernia repair. When diagnosed with inguinal hernia and tension-free mesh hernia repair, samples who are 20-64 years old are considered non-elderly patients. Body mass index (BMI) is used to determine patients' nutritional status. Patients with a BMI $\geq$ of $30 \mathrm{~kg} / \mathrm{m}^{2}$ are categorized as patients with obesity. Meanwhile, non-obese patients are those with a BMI of $<30 \mathrm{~kg} / \mathrm{m}^{2}$. The last factor is diabetes mellitus. The criteria used to categorize patients are a random blood glucose level of $\geq 200 \mathrm{mg} / \mathrm{dL}$ before the operation, accompanied by classic diabetes mellitus. Patients who have a history of diabetes mellitus written in their medical records are also included in the diabetes mellitus category.

The collected data are then processed using SPSS 18.0 to conduct the Pearson chi-square test and Fisher's exact test. The significance level ( $\alpha$ ) used is $0.05(5 \%)$. This study has obtained ethics approval from

Table 1. Sample characteristics of the study.

\begin{tabular}{lcc}
\hline \multicolumn{1}{c}{ Characteristics } & Frequency (n) & Percentage (\%) \\
\hline Gender & 117 & 95.9 \\
$\quad$ Male & 5 & 4.1 \\
$\quad$ Female & & \\
Age & 70 & 57.4 \\
20-64 years & 52 & 42.6 \\
$\geq 65$ years & & \\
Types of Hernia & 57 & 46.7 \\
Right Lateral (Indirect) Inguinal Hernia & 62 & 50.9 \\
Left Lateral (Indirect) Inguinal Hernia & 1 & 0.8 \\
Right Medial (Direct) Inguinal Hernia & 2 & 1.6 \\
$\quad$ Left Medial (Direct) Inguinal Hernia & & \\
\hline
\end{tabular}

the Ethics Committee of each institution prior to the study conducted.

\section{RESULTS}

During 2019-2020 at seven regional public hospitals in Bali, 670 patients had a tension-free mesh hernia repair and did postoperative control within one year after the procedure was done. Patients with incomplete medical records and patients who fit the exclusion criteria have been excluded from that number. Among the 670 patients, there are 26 cases of SSI, making the incidence of SSI in inguinal hernia repair $3.8 \%$ in $2019-2020$. There is also a decline in the number of patients that underwent the procedure from 2019 to 2020. From the 670 patients stated above, 410 had the procedure in 2019 and 210 in 2020.

As mentioned above, a total of 122 samples are included in this study. They are divided into two groups, the case group with 61 samples and the control group with 61 samples. According to their postoperative control records, the case group are patients who had SSI, while the control group is those who did not have SSI. From Table 1, it is evident that most samples are male $(95.9 \%)$, with females making up only $4.1 \%$ of the total 122 samples in this study. Left lateral (indirect) inguinal hernia is the most common type of inguinal hernia found in this study, with 62 samples (50.9\%). In terms of age, 70 samples are aged between 20 to 64 years old $(57.4 \%)$.

Factors influencing $\mathrm{SSI}$ in inguinal hernia patients undergoing tensionfree mesh hernia repair Elderly patients

In comparison, there are more elderly patients in the case group than in the control group. This shows that elderly

Table 2. Factors influencing SSI in inguinal hernia patients undergoing tension-free mesh hernia repair.

\begin{tabular}{|c|c|c|c|c|c|c|}
\hline \multicolumn{2}{|c|}{ Risk Factors } & $\begin{array}{c}\text { SSI (+) } \\
\text { n (\%) }\end{array}$ & $\begin{array}{l}\text { SSI (-) } \\
\text { n (\%) }\end{array}$ & $\begin{array}{l}\text { Total } \\
\text { n (\%) }\end{array}$ & p-value & OR \\
\hline \multirow{2}{*}{ Elderly patients } & Yes & $32(61.5 \%)$ & $20(38.5 \%)$ & $52(100 \%)$ & \multirow{2}{*}{0.028} & \multirow{2}{*}{2.262} \\
\hline & No & $29(41.4 \%)$ & $41(58.6 \%)$ & $70(100 \%)$ & & \\
\hline \multirow{2}{*}{ Obesity } & Yes & $8(88.9 \%)$ & $1(11.1 \%)$ & $9(100 \%)$ & \multirow{2}{*}{0.032} & \multirow{2}{*}{9.057} \\
\hline & No & $53(46.9 \%)$ & $60(53.1 \%)$ & $113(100 \%)$ & & \\
\hline \multirow{2}{*}{ Diabetes mellitus } & Yes & $15(88.2 \%)$ & $2(11.8 \%)$ & $17(100 \%)$ & \multirow{2}{*}{0.001} & \multirow{2}{*}{9.620} \\
\hline & No & $46(43.8 \%)$ & $59(56.2 \%)$ & $105(100 \%)$ & & \\
\hline
\end{tabular}


patients are more likely to get SSI after tension-free mesh hernia repair than non-elderly patients. Upon analysis, there is a significant relationship between the incidence of SSI and elderly patients. The risk of SSI in elderly patients who had tension-free mesh repair is two times higher than non-elderly patients $(<65$ years old) (as shown in Table 2).

\section{Obesity}

From the total 122 samples included in this study, only 9 are categorized as obese. However, when compared between the case and control group, 8 out of 9 obese patients are found in the case group. From the analysis, it is found that there is a significant relationship between the incidence of SSI and obesity. SSI risk in patients with obesity who had tension-free mesh repair is nine times higher than nonobese patients (as shown in Table 2).

\section{Diabetes mellitus}

The number of patients with diabetes mellitus found among the total samples is 17 samples. They make up only a fraction of the 122 samples, but analysis showed a significant relationship between SSI incidence and diabetes mellitus. From Table 2, it is shown that 15 out of the 17 samples with diabetes mellitus are found in the case group. Meaning patients with diabetes mellitus are more likely to get SSI after tension-free mesh hernia repair. This is supported by the result of odds ratio (OR), which is 9.6, meaning that SSI risk in patients with diabetes mellitus who had tension-free mesh hernia repair is 9.6 higher than patients without diabetes mellitus (as shown in Table 2).

\section{DISCUSSION}

This study showed that the incidence of SSI in inguinal hernia repair in seven regional public hospitals in Bali during 2019-2020 is $3.8 \%$. That number is higher than the risk of SSI in clean operation procedures, which is said to be less than $2 \%{ }^{16}$ Therefore, this study was done to analyze preoperative factors related to SSI incidence in inguinal hernia patients. The decline in the number of patients and procedures done from 2019 to 2020 is mainly caused by the COVID-19 pandemic, which discourages patients from going to hospitals for non-emergency conditions. Many other elective procedures have also seen a decline in numbers since the pandemic started in 2020. The samples in this study are dominated by male patients (95.9\%), supporting the theory that men have a higher risk of getting an inguinal hernia than women. While men have a risk of $27-43 \%$ getting an inguinal hernia in their lifetime, women getting an inguinal hernia in their lifetime is only $3-6 \% \cdot{ }^{10}$ Factors that increase the risk of getting inguinal hernia includes an increase in intra-abdominal pressure from chronic coughing and sneezing, weightlifting, and weakness in the abdominal wall muscles caused by aging. ${ }^{14,17,18}$

Left lateral (indirect) inguinal hernia is the most common type of inguinal hernia found in this study, making up 62 out of the 122 samples (50.9\%). It is followed by a right lateral (indirect) inguinal hernia, making up 57 out of 122 samples (46.7\%). The result from this study is different from what the theory states that indirect inguinal hernia is more commonly found on the right side, as a result of the delay in processus vaginalis closure on the right side of the body caused by the delayed process of right testes descend during fetal development. ${ }^{13}$ Other studies, such as those done at Rumah Sakit Umum Anutapura Palu and RSUP Prof. DR. R. D. Kandou Manado, showed that right lateral (indirect) inguinal hernia is the most commonly found type of inguinal hernia. ${ }^{19,20}$

In recent decades, there has been an increase in the life expectancy rate following the development and discoveries made in the medical world. This increase in life expectancy means many elderly patients live with chronic diseases due to aging. ${ }^{13}$ The aging process involves a decline in the organ systems' physiological functions: the immune system. ${ }^{13}$ Other than the impaired function of the immune system, old age is also associated with chronic and comorbid diseases that increase the risk of SSI and the risk of surgical complications in general. ${ }^{21}$

Tension-free mesh hernia repair is a clean surgical procedure, meaning that it has a very low risk of SSI. ${ }^{22}$ But certain conditions can increase the said risk, including the patient's nutritional status.
According to an article in the Journal of Leukocyte Biology from 2018, patients with obesity experience increased inflammation markers in their plasma, which causes a persistent immune dysregulation. ${ }^{23}$ Again, the immune system plays a crucial role in the incidence of infections, in this case, SSI after inguinal hernia repair. Other studies stated that obesity increases SSI risk as it causes prolonged wound healing and decreases subcutaneous oxygen levels during the operation. ${ }^{24,25}$

Such as the previous two factors, the immune system also serves as a bridge between diabetes mellitus and SSI incidence. A study conducted at The F Affiliated Hospital of Shantou University Medical College found that diabetes mellitus is one of the risk factors for SSI in inguinal hernia repair. ${ }^{24} \mathrm{~A}$ systematic review showed a similar result, stating that diabetes mellitus is not only the independent risk factor for inguinal hernia repair but also other surgical procedural. ${ }^{26}$ Diabetes mellitus causes a state of immunosuppression which puts the patients at a greater risk of infection, and microangiopathy, which leads to prolonged wound healing. Prolonged wound healing increases the risk of infection as it becomes a possible port d'entry for pathogens. ${ }^{27,28}$ Preoperative assessment of patients is essential to find certain risk factors such as age, nutritional status, and certain chronic or comorbid diseases that might increase their risk of surgical complications and disruptive outcomes of the procedure. For elective procedures, in this case, inguinal hernia repair, preoperative assessment done a few days before it will benefit the patient as preoperative examinations and management can be done to ensure that the patient is in the appropriate condition for surgery.

The limitation of this study is that it is done using medical records from seven different regional public hospitals, which means there will be differences in interpretation since other people do the assessments and recordings.

\section{CONCLUSION}

This study concludes that there is a relationship between elderly patients, obesity, and diabetes mellitus with the incidence of SSI in inguinal hernia patients 
undergoing tension-free mesh hernia repair. Moreover, the risk of SSI in elderly patients increases by 2 -fold, in obese patients by 9 -fold, and in patients with diabetes mellitus by 9.6 -fold. To reduce SSI incidence, especially in inguinal hernia patients, further studies must be done on the preoperative, perioperative and postoperative management of inguinal hernia patients.

\section{ACKNOWLEDGMENTS}

We are thankful to all the staff for helping with the data retrieval.

\section{CONFLICT OF INTEREST}

We declare that there were no conflicts of interest in this study.

\section{FUNDING}

The authors are responsible for the study funding without a grant, scholarship, or any other funding resources.

\section{AUTHOR CONTRIBUTION}

All of the authors are equally contributed to the study.

\section{REFERENCES}

1. Leaper D, Edmiston C. WHO: Global Guidelines For The Prevention of Surgical Site Infections. J Hosp Infect. 2017;95(2):135-136.

2. Keast D, Swanson T. Ten top tips : managing surgical site. Wounds Int. 2014;3(7):13-8.

3. NICE. Exceptional surveillance of surgical site infections: prevention and treatment (NICE guideline 125). London: National Institute for Health and Care Excellence. Available from: https://www.ncbi.nlm.nih.gov/books/ NBK552252/.

4. Garner BH, Anderson DJ. Surgical Site Infections: An Update. Infect Dis Clin North Am. 2016;30(4):909-29.
5. Sattar F, Sattar Z, Zaman M, Akbar S. Frequency of Post-operative Surgical Site Infections in a Tertiary Care Hospital in Abbottabad, Pakistan. Cureus. 2019;11(3): 4243.

6. Noch L, Rompas S, Kallo V. Hubungan Tingkat Pendidikan Dan Sikap Dengan Pelaksanaan Prosedur Tetap Perawatan Luka Di Ruang Perawatan Bedah Badan Rumah Sakit Daerah Kabupaten Banggai. J Keperawatan UNSRAT. 2015;3(1):1-8.

7. Zinn BJ, Swofford V. Quality-improvement initiative: Classifying and documenting surgical wounds. Wound Care Advis. 2014;3(1):7-13.

8. Kurnia A, Tripriadi E, Andrini F. Gambaran Penderita Infeksi Luka Operasi Pada Pasien Pasca Operasi Bersih (Clean) Di RSUD Arifin Achmad Provinsi Riau Periode Oktober Desember 2013. JOM FK. 2015;2(2):1-15.

9. Elbur AI, Yousif M, ElSayed A, AbdelRahman M. Prevalence and predictors of wound infection in elective clean and clean/contaminated surgery in Khartoum Teaching Hospital, Sudan. Int $J$ Infect Control. 2012;8(4):1-10.

10. Köckerling F, Simons MP. Current Concepts of Inguinal Hernia Repair. Visc Med. 2018;34(2):145-50.

11. Pardhan A, Mazahir S, Alvi AR, Murtaza G. Surgical site infection following hernia repair in the day care setting of a developing country: A retrospective review. J Pak Med Assoc. 2013;63(6):760-2.

12. Cai LZ, Foster D, Kethman WC, Weiser TG, Forrester JD. Surgical Site Infections after Inguinal Hernia Repairs Performed in Low and Middle Human Development Index Countries: A Systematic Review. Surg Infect (Larchmt). 2018;19(1):11-20.

13. Townsend CM, Beauchamp RD, Evers BM, Mattox KL. Sabiston Textbook of Surgery. 20 ed. New York: Elsevier Inc; 2017.

14. Sjamsuhidajat R, de Jong W. Buku Ajar Ilmu Bedah. 4 ed. Jakarta: Penerbit Buku Kedokteran EGC; 2017.

15. Towfigh S. Inguinal Hernia: Four Open Approaches. Surg Clin North Am. 2018;98(3):623-36.

16. Zinn J, Swofford V. Quality-improvement initiative: Classifying and documenting surgical wounds. Wound Care Advis. 2014;3(1):8-13.

17. Öberg S, Andresen K, Rosenberg J. Etiology of Inguinal Hernias: A Comprehensive Review. Front Surg. 2017;4(September):1-8.
18. Vad MV, Frost P, Rosenberg J, Andersen JH, Svendsen SW. Inguinal hernia repair among men in relation to occupational mechanical exposures and lifestyle factors: A longitudinal study. Occup Environ Med. 2017;74(11):769-75.

19. Sesa IM, Efendi AA. Karakteristik Penderita Hernia Inguinalis Yang Dirawat Inap di Rumah Sakit Umum Anutapura Palu Tahun 2012. J Kesehat Tadulako. 2015;1(1):1-10.

20. Rawis CG, Limpeleh HP, Wowiling PA V. Pola Hernia Inguinalis Lateralis di RSUD Prof. Dr. R. D. Kandou Manado Periode Agustus 2012 - Juli 2014. e-CliniC. 2015;3(2):1-5.

21. Horasan ES, Dağ A, Ersoz G, Kaya A. Surgical site infections and mortality in elderly patients. Med Mal Infect. 2013;43(10):417-22.

22. Kulacoglu H. Hernia, Mesh, and Topical Antibiotics, Especially Gentamycin: Seeking the Evidence for the Perfect Outcome. Front Surg. 2015;1:1-4.

23. Frydrych LM, Bian G, O'Lone DE, Ward PA, Delano MJ. Obesity and type 2 diabetes mellitus drive immune dysfunction, infection development, and sepsis mortality. J Leukoc Biol. 2018;104(3):525-34.

24. Zhuo Y, Li X, Chen J, Zhang Q, Cai D. Surgical site infection following elective mesh repair of inguinal hernia: an analysis of risk factors. Research square. 2020;1-24.

25. Yang H, Xiong Y, Chen J, Shen Y. Study of mesh infection management following inguinal hernioplasty with an analysis of risk factors: a 10-year experience. Hernia. 2019;24(2):301-5.

26. Al-mohawis LT, Alfraikh SH, Alfalahi I, Alotaibi F, Alqarni AH, Altamimi IM, et al. Risk of Surgical Site Infection (SSI) in Diabetes Mellitus Patients: A Systematic Review and Metaanalysis. Ann Med Heal Sci Res. 2021;11:1199202.

27. Liu JM, Deng HL, Chen XY, Zhou Y, Yang D, Duan MS, et al. Risk Factors for Surgical Site Infection after Posterior Lumbar Spinal Surgery. Spine (Phila Pa 1976). 2018;43(10):732-7.

28. Andersen BM. Prevention of Postoperative Wound Infections. Prevention and Control of Infections in Hospitals. 2019; 377-437.

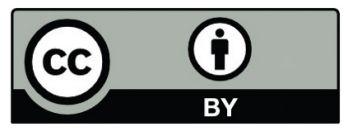

This work is licensed under a Creative Commons Attribution 